\title{
PARENTAL ATTITUDES TOWARDS VOCATIONAL EDUCATION: IMPLICATIONS FOR COUNSELLING
}

\author{
OKOCHA, Maria Mrs. \\ School Counsellor, \\ D. S. C. Technical High School \\ Delta Steel Company, Ovwian-Aladja, Delta State
}

\begin{abstract}
This paper looked at one aspect of societal attitudes towards vocational education by conducting a survey involving 200 parents in Udu Local Government Area of Delta State. The result of the survey clearly showed that although parents recognize the employment value inherent in vocational education, they are still prepared to accept the superiority of socially prestigious and white-collar professions over technical related occupations. Simple percentages and frequencies were used to obtain data for this study. The paper concluded by examining the implications of these findings for guidance and counselling services in Nigeria.
\end{abstract}

Key Words: Parental Attitude, Vocational Education, Counselling, skill training, school curriculum, grammar education

\section{Introduction}

Innovations relating to vocational education have been introduced as a way of reducing "waste' of talent often associated with conventional schools. The rationale or vocational needs would provide a more productive stimulus to the economy. In Nigeria, for example, the New National Policy on Education (2004) has not only advocated the integration of productive work into learning but also stipulated the establishment of multi-purpose vocational centres in order to facilitate the training of artisans, craftsmen, technicians, etc.

In spite of the growing awareness of the need for skill training in development efforts, there seems to be lack of adequate information on the concept of linkage between education and working life; for instance, the implications of innovations and policy formulations concerning vocational education programmes in the context of individual. 
Needs and national priorities may not be fully understood by parents and the public at large. As Obanya (1984) aptly notes "most queries and reflections on the 6-3-3-4 which provide for vocational education have been by non -educationalists." It is therefore against this background that this study sets out to investigate parental attitude towards vocational education, and the role of counselling. The assumption here is that parents do play a" major role in the socialization, education and career decision processes of their children.

Education generally aims at including knowledge, attitudes, skills, values, and beliefs into an individual to assist him/her achieve a reasonable degree of competence in the various facets of everyday life. In a nutshell, therefore, the main function of education is the provision of appropriate skills, abilities and competence of both mental and physical nature as necessary equipment for the individual to live productively in the society. Vocational education is a facet of technical education that has more to do with practical work leading to a particular occupation or career. It provides activities for learning by doing and enables individual differences to be catered for. In fact, no attempt is made to create homogeneities in groups of children by practices like streaming and ability grouping. This means that in vocational education programmes, there are less stiff formalities in classroom, thus providing opportunity to sit together thus, recognizing the peer group influence on learning (i.e. learning how to work as a group).

Undoubtedly, it is obvious that in this type of programme, children find satisfaction and joy in learning. A lot more advantage abound in this type of educational programme in the course of learning such as willingness and eagerness of children to learn and focusing talent efforts upon the critical domestic issues of development. Vocational education can provide rehabilitation needed in work places for workers. This is important in order to up-date skills needed for technological improvement in our industries and society at large.

Timar (1983) explains that although the acquisition of skills is an aptitude for quick perception and quick solution of problems, all requirements for a good worker makes selection necessary. Continuing, he explains that:

Acquisition of required occupational skills entail carefully and methodically prepared special courses of fairly long duration even for the performance of a restricted number of operations. 
Within the past three decades, there have been lots of changes within the society, for instance technological changes to the effect that the present grammar type of education can no longer satisfactorily meet the requirements of the society and that of the individual. This has manifested itself in the unemployment and under-employment problems that are experienced within the country. Graduates of this grammar type of educational institutions find it difficult to fit into any type of skilled or semi-skilled labour, while 'at the same time it is becoming apparent that the majority of them cannot afford the expenses to further their education. This situation clearly indicates that there is a mismatch between the education system (grammar) and what the society needs. Furthermore, this situation has challenged the status quo in our education system which would draw its materials and practical experiences from the world around the child's environment. In this vain Simons (1980) writes:

The concentration on mental and the theoretical exercises rather than manual and practical experience, has prepared most students for neither jobs, nor family, nor responsibilities of citizenship.

This suggestion that school should provide skill training and prepare children for meaningful life in their local communities appeared to be a necessary innovation to meet the demands of recent trends in social and economic change. Blaus (1967), for example, sees small experimentation with the 6-3-3-4 educational approach as the only way to reduce the wasteful mismatch between education and employment.

It was against this background of concern that the federal Government of Nigeria summoned, in 1969, a National Curriculum Conference of distinguished education experts to deliberate on all aspects of the country's education policies and programmes. In the process of articulating the role and tasks of Nigerian Primary School, the Conference noted that primary school education will continue to prepare most children for life while a few talented ones must be given the opportunity to proceed to secondary school for the development of the future intermediate and high level man-power needs of the country. In this context the Conference suggested that the primary school curriculum must be weighted more heavily on preparing the majority of children for life since primary education may turn out to be terminal for this category of children. In specific terms, the primary school curriculum should provide, amongst other things, encouragement of aesthetic, creative and 
musical activities, the teaching of local crafts, domestic science and agriculture. Upon graduation from primary school, those who cannot proceed to junior secondary school, but would not enter the labour market, will have some from of vocational training in the craft school for three years. The junior secondary educational system provides some prevocational courses which include practical agriculture wood-work, electronics, mechanics, carpentry, masonry, technical drawing, local crafts home economics, business studies etc. The Trade School is another area where some forms of vocational educational programmes take place. The intakes are graduates of junior secondary school and the duration is three years. This whole programme has been discarded or partially discarded for the U.B.E. Scheme.

\section{The Problem}

In spite of the apparent weaknesses of the grammar education and the pressing need for vocational education, experiment to implement the syllabus seemed to have failed, because attempts to implement the programmes are only partially done or neglected. Furthermore, although policy statements and issues, scholarly lectures and discussions at seminars and conferences stand to point out the need for vocational education, the training of top-cadre elites through the grammar school type of education has essentially remained the dominant practice.

This has created a paradoxical situation where there is need for vocational education, yet the society's antipathy and parents' avowed disapproval of vocational training for their children seem to exist. Although Fafunwa (1984) argues that the result of his research conducted on the education system reveals an unanimity of both literate and illiterate parents on their: dissatisfaction with primary and secondary grammar education; yet opinions are that vocational education, which was designed to correct the lapses of the former system, is still boarded on ridicule, insolence because of society antipathy and parents avowed disapproval of discouragement of career training for their children in technical education.

An essential ingredient in the successful and effective implementation of an innovation such as vocational education is societal reaction. Schools are not free agents and as such they do not operate in a vacuum. Their growth, development and sustenance are largely dependent on society support, attitudes and manipulations. For example, many societies have encouraged the perpetuation of bookish and academic oriented learning and discouraged the development of practical and applied knowledge type of learning. It is therefore against 
this background that this study set to investigate parental attitudes in Nigeria toward vocational education in Nigeria. The problem therefore is: To what extent will the parental attitude influence the development of vocational education in Nigeria?

\section{Research Question}

To what extend will parental attitudes toward vocational education influence their willingness to allow their children take vocational education as a career?

\section{Hypothesis}

The following hypothesis have been formulated to guide the study.

Ho: There will be no significant difference in parental attitude toward vocational education and their willingness to allow their children take a career in vocational education.

\section{Procedure}

The subject for this study, comprising 200 parents, was drawn from locations in Udu Local Government Area of Delta State. The study, which is part of a wider project investigating the nature and extent of societal attitudes to vocational education, employed 'Opportunity Sampling' techniques to select the parent respondents.

Table 1: A Breakdown of the Occupational Categories of Parent Respondents

\begin{tabular}{|l|c|}
\hline Occupational groups & Percentage \\
\hline Teaching Staff (University Lecturers and School Teachers) & 17.5 \\
Secretarial and Clerical Staff & 10.5 \\
Businessmen/ Women & 9.0 \\
Public servants (drivers, technician's porters, etc.) & 9.0 \\
Medical Doctors & 5.5 \\
Lawyers & 4.0 \\
Petty Traders & 4.0 \\
Farmers & 3.5 \\
Household staff & 2.5 \\
Scientists & 1.5 \\
Others & 33.0 \\
\hline \multicolumn{2}{|c}{} \\
\hline
\end{tabular}


In this context any parent (male or female) found at a particular time or place during the surveying exercise was requested to participate. Udu Local Government Area is known for its social heterogeneity, and the parent respondents would be expected to provide a reasonably representative sample for the wide range of socio-economic and educational level characteristics. Indeed, a preliminary analysis of the data collected from the survey shows that the parents who participated in this study represent the various socio-economic groups in the society (see Table 1 for details).

To determine the nature and extent of parental attitudes towards vocational education, a ten-item questionnaire was designed and distributed to participating parents. The items on the questionnaire provided a wide range of response options in respect to the subject' attitude and pre-dispositions to vocational education. Some were 4 scale attitude questions, while others were intended to elicit simple 'Yes/ $\mathrm{No}$ ', 'favourable/unfavourable', or 'Positive /Negative' responses.

\section{Results}

Table 2 below tabulates the Parents' views on the appropriateness and relevance of the school system.

Table 2 Parents' Views on the Appropriateness and Relevance of School Systems

\begin{tabular}{|c|c|c|}
\hline School systems & Frequency & Percenta \\
\hline Technical Education & 138 & 69 \\
\hline Vocational Education & 20 & 10 \\
\hline Academic (Grammar School Type) & 34 & 17 \\
\hline Teacher Education & 8 & 4 \\
\hline Total & 200 & 100 \\
\hline
\end{tabular}

From the data shown in Table 2, it is clear that a sizeable proportion $(79 \%)$ of parents feel that vocational and technical education programmes are appropriate and relevant for the society in general at this stage of Nigerian's awareness of the priority needs of the country in terms of economic productivity and technological progress.

To probe parents on this issue more deeply, they were asked what recommendations they would make about Nigerian educational system if given the chance to do so. The analysis of responses showed that the overwhelming majority (94\%) support the establishment of more vocational and skill training schools, while only 6 percent of the parents are in favour of grammar schools. 
This phenomenon of parent acknowledgement of the value and relevance of vocational education vis-à-vis societal needs and priorities do not necessarily mean that vocational education is held in high esteem socially by the general public. In answer to the question 'from discussions on vocational education with friends, relations, your children, and others, what do you think is the most common view held by all? , many parents $(69 \%)$ feel that the public, in general, sees vocational education as a field of study best suited for the low socio economic status group in the society.

When asked to express their opinions about the value of vocational education, a substantial majority (89.5\%) of parents responded by saying it provided skills for employment. This parental perception of the employment value of vocational education is further confirmed by the analysis of the parents' responses to a similar question. A considerable proportion $(79 \%)$ of parents said that they would change their attitudes in the positive direction (assuming they had negative attitudes to vocational education initially) if they became aware of the technological and employment opportunities provided by vocational education programmes.

Considerations of employment opportunities also appear to have shaped the parents' response to the question 'Would you like your child's education to be geared towards vocational education courses? In reply to this question, the majority (64\%) of the parent respondents said 'Yes', while the rest $(36 \%)$ said 'No'. In the same vein, skill acquisition for employment in the labour market was in all probability an important factor in the calculation of the many $(76 \%)$ parents who said they would react positively if their children decide to become technicians by following a course in vocational education. An interesting finding to emerge from the analyses of the responses is the high esteem in which white-collar jobs are held by parents.

Table 3. Job Aspirations of Parents for Their Children

\begin{tabular}{|c|c|c|c|}
\hline \multicolumn{2}{|c|}{ Type of Occupation } & Frequency & Percentage \\
\hline $\begin{array}{l}\text { Law } \\
\text { Medicine }\end{array}$ & $\begin{array}{l}\text { Academic } \\
\text { Oriented }\end{array}$ & 186 & 93 \\
\hline $\begin{array}{l}\text { Building } \\
\text { Carpentry } \\
\text { Technical }\end{array}$ & $\begin{array}{l}\text { Technical, } \\
\text { Vocational or } \\
\text { Mechanical } \\
\text { Oriented }\end{array}$ & 14 & 7 \\
\hline & $\overline{\mathrm{AL}}$ & 200 & 100 \\
\hline
\end{tabular}


As shown in Table 3, the overwhelming majority (93\%) of the parent respondents seek academic oriented occupation for their children while only 7 percent would prefer their children to take up jobs with technical bias. This in a way is a re-affirmation of the wider societal prejudice against technical oriented jobs and suggests that although parents recognize the employment value in vocational education, they would still like their children to take up 'prestigious' professions like law, Medicine and Accountancy.

\section{Discussion}

One general observation to emerge from this survey is the pressing need to link schools to the employment market, and thereby make education functionally relevant by narrowing the gap between theoretical study and practical work. This is reflected in the parents' inclination to perceive vocational education in terms of material and employment opportunities. This seemingly, positive shift in favour of vocational education, however, should not be simply interpreted as a manifestation of real change in attitudes. As indicated earlier, a sizeable majority of parents still prefer white-collar jobs for their children when it comes to actual career choices and aspirations. Although parents are aware of the employment value in vocational education, they are still prepared to accept the superiority of socially prestigious professions like Law, Medicine and Accountancy over technical oriented jobs. This is a reflection of the deeper societal prejudice against manual labour and in a way confirms the current validity of the African legislator's statement, as cited by Fafunwa (1963), that: Vocational education is urgently needed for our development and should be encouraged, but not for my son.

\section{Implications for Counselling}

The findings of this study, point to the need to utilize guidance and counselling support services with a view of generating a conducive climate for accepting innovations in educational programmes and career opportunities.

While the prescription of educational programmes and innovations in terms of stated aims and objectives is mainly the concern of policy makers, the central task of guidance and counselling teams is to provide a clear understanding of the relative priority of such programmes and objectives. This can be done by channelling information on the educational and career implications of new programme issues (e.g. vocational education) to the clientele (i.e. parents) and by communicating 
feedback on matters concerning innovations from parents to programme formulators.

In this context, the onus is therefore on guidance and counselling support services to devise effective ways of facilitating the dissemination of innovations both vertically and horizontally, and both within and outside the school system in order to achieve meaningful of attitudes in desired direction.

\section{References}

Adesina, (1983) Nigerian Education: trend and Issues, Ile-Ife, UNIFE press

Blaus, P.M. (1967) The American Occupational structure. New York Wiley Inc.

Fafunwa, B., (1963). "African Education and social Dynamics" West African Journal of Education, VII, 2.

Fafunwa, B.(1974). New perspective in Africa Education. Lagos, Macmillan Pub

Federal Republic of Nigeria (2004). National Policy on Education (Revised). Lagos: Federal Government Press.

Ferning, L, (1980). The place of Information in Educational Development. Paris, UNESCO.

Ibid (1981). Guideline for the fourth Nation Development plan 1981-85," Lagos Federal Ministry of planning, Lagos

Obanya P. (1982). The Educationist and National policy on Education" journal of Nigerian Education Research Association, 4,(1) 22-31

Obanya, P., (1984). "The Educationist and National Policy on Education", Journal of Nigerian Educational Research Association, 4. (1).

Ozoro, O. (1982). "Problem Area in Nigerian Education. The School Curriculum Technology in secondary school" Nigerian journal of technical Education 1, (2) 21 - 29.

Yoleye E.E. (1984)" Contemporary Issues in Implementing the New Nation policy Education " journal of Nigerian Education Research Association 4(1) 10-21. 